\title{
Online interaction impacts on learning: Teaching the teachers to teach online
}

Gail Wilson

\author{
University of Western Sydney
}

\section{Elizabeth Stacey}

Deakin University

This paper explores the importance of interaction in the online teaching environment and the important role of staff development in developing teacher presence online. Professionally developing staff to use information and communication technologies is viewed from the standpoint of diffusion of innovation, moving from early adopters to mainstream majority, and targeting staff development at this latter group. Approaches to staff development using information and communication technologies are described, and recommendations for staff development for online teaching

are made.

\section{Introduction}

New technologies have changed the nature of open and distance education in the last decades by providing a way for communities of learners and their teachers to interact with one another despite being situated in differing geographical locations. Online interaction is also increasingly being introduced into a flexible model of learning for campus based learners. Research has shown that the electronic environment can be structured for effective social constructivist learning (Stacey, 2002; Bonk \& Cunningham, 1998) that requires an interactive online discussion. Such models of collaborative learning are becoming almost mandatory in course design and delivery as e-learning is being introduced into institutional policies (eg Deakin University, 2003). This raises the issue of how online technologies can be integrated into teaching in higher education, as not all staff enthusiastically embrace the change that such new technologies and pedagogies can bring. This paper will discuss the need for interaction and its provision online and will review staff response to new technologies. Models of professional development will be compared and critiqued with discussion of institutional practices to illustrate these. 


\section{The need for interaction}

The importance of interaction in forms of flexible, online and distance education have been researched and described at length - whether learners interacting with individualised computer programs, or learner-to-teacher or learner-to-learner interaction that at a distance requires the mediation of technology (Moore, 1989; Garrison \& Anderson, 1998). Sims (2003) in researching the expectations of learners for an interactive online environment that engages them concluded that learner control of the environment with active communication providing feedback was an essential component of interactivity. The revival of interest in Vygotskian social constructivism as an explanatory theory for the effectiveness of online learning claims interactive learning, as achieved by the process of communicating electronically, enables the learners to actively construct their own perspectives which they can communicate to a small group.

Using group conferences as a central communication space provides a means of enabling the groups to socially construct knowledge. Stacey (1999) found that small collaborative groups, when committed to regular online interaction, could learn extremely effectively at a distance. The students' process of learning was achieved through collaborative behaviours, from their sharing the diverse perspectives of the other group members, to being able to seek feedback and clarify ideas through the group's communication, either electronic or through other forms of communication stimulated by the electronic group communication. They sought group solutions for problems through discussion, and through such discussions were able to practise the new language of the knowledge community they were seeking to join, within a comfortable small group environment. Group electronic discussion and sharing of resources gave them an environment for actively constructing new ideas and concepts and enabled them to learn effectively. It was found that learning collaboratively through group interaction was achieved by the development of a group consensus of knowledge, through communicating different perspectives, receiving feedback from other students and tutors, and discussing ideas, until a final negotiation of understanding was reached. In this research study, the interactive communication process was facilitated through the computer mediated communication which established a vehicle for socially constructed learning.

An increasing amount of research and evaluation is being reported on this type of online interactivity (Berge, 1999; Garrison, Anderson, \& Archer, 2000). In the field of distance education, Trentin (2000) writes about the importance of interaction if quality is to be raised in distance education, and he particularly sees the 'third generation' of online technology as a way of increasing interaction and therefore increasing quality. He quotes 
Moore's (1989) quality analysis model, based on interaction between participant and learning material, between participant and tutors/experts, and among participants (Trentin, 2000; p.19), and concludes that facilitating interaction among participants raises quality in distance education. Flottemesch (2000) reports on a range of research into interactivity in distance education, supporting the contention that students tend to judge a distance education course according to their perception of the teacher's interactivity. Such perceptions underline the importance of providing all teachers with effective professional development so that they can confidently establish teacher presence online (Anderson et al., 2001; Murphy, Smith \& Stacey, 2002) which, though it may not be the main component in the effectiveness of the learning online, is important in structuring and facilitating an effective online learning experience, and helping to establish an online learning community among the students.

Muirhead (2000), in researching interactivity which he defined as 'communication, participation and feedback' (p.1), found that both students and teachers had to be active participants in a relevant academic discussion for this interactivity to be as effective as is assumed. Bullen (1998) found in researching distance students' critical thinking processes through online interaction that, though the instructor consistently responded in blocks of interactive teaching, some students needed continuous (at least daily) teacher presence online to sustain a virtual community of inquiry, although Murphy et al. (2002) recommended strategies for teacher management of the online environment to provide such teacher presence in a more time effective way. Northrup's (2001, p.31) framework of strategies to facilitate interaction on the Web is framed within five interaction attributes: 1) interaction with content, 2) collaboration, 3) conversation, 4) intra-personal interaction, and 5) performance support. The teacher's understanding in structuring and facilitating interaction through such a web environment requires effective staff development for them to be confident and competent online teachers.

\section{Technology adoption patterns of academic staff}

The diffusion of innovation perspective dominates much of the literature that addresses professional development for academic staff in relation to the use of information and communication technologies in the move to online teaching. Though currently in its fourth edition, Rogers' (1995) theory of adoption of technology, Diffusion of Innovations, was originally written in 1960 in a different technological world to the present; yet it has become a framework used frequently in publications and discussions for introducing new technology to academic staff. Diffusion is defined as 'the process by which an innovation is communicated through certain channels 
over time among the members of a social system...a kind of social change' (p.5). Rogers' theory of individual innovativeness suggested that people are inherently more or less predisposed to innovative behaviour. He theorised that individual adoption rates of innovation are usually distributed along a bell shaped curve and can be grouped under five categories: innovators, representing $2.5 \%$ of the population; early adopters, representing $13.5 \%$ of the population; early majority, representing $34 \%$ of the population; late majority, representing $34 \%$ of the population, and laggards, representing $2.5 \%$ of the population.

\section{Early adopters versus mainstream majority}

The innovator is the first to try out new products and processes. Rogers (1995) described them as 'venturesome'. The early adopters take up and utilise the innovation. They are the 'techies' and the visionaries who see technology as fun and challenging, and use technology to achieve 'breakthrough' improvements in teaching and learning. They are risk takers, experimenters, and horizontally networked, that is, their personal networks extend to interdisciplinary and cross-functional groups (Geoghegan, 1995). Research undertaken by Jacobsen (2000) found that the early adopters are confident in their ability to integrate technology into instruction and make adoption of technology look relatively easy, thereby disguising the knowledge and skills that mainstream staff need in order to adopt. Other adjectives used to describe early adopters include 'lone rangers', 'isolated enthusiasts' (Taylor, 1998), and 'online mavericks' (Ellis and Phelps, 2000)

On the other hand, the mainstream majority of staff favour evolutionary change, are pragmatic or conservative, risk averse, and seek proven applications of the use of technology in teaching. In contrast to the early adopters, this group are 'vertically networked', that is, their person networks tend to be concentrated within a single discipline area (Geoghegan, 1995). Moore (1991; p.20) who was influenced by Rogers' theories, wrote 'of the deep and dividing chasm that separates the innovators and early adopters from the remaining groups' (early and late majorities and laggards). Geoghegan (1995; p.3) applied Moore's chasm concept to the adoption of instructional technology in higher education, and affirmed 'the veritable chasm between the early adopters of instructional technology and the much larger, effectively unengaged mainstream faculty population'. A study conducted at a large research university in Canada confirmed this gap between early adopters and mainstream faculty (Anderson, Varnhagen \& Campbell, 1998). It concluded that 'comprehensive adoption strategies cannot be based on support of early adopters, but must be designed to appeal to the mainstream faculty', drawing from the mainstream faculty the role models 
that are essential for the diffusion of innovation, staff who are 'better integrated into the traditional administrative and social norms of faculty culture' (p.94). These statements illustrate a tendency in the literature to speak about two groups of staff in relation to the uptake of information and communication technologies in teaching and learning: the early adopters (innovators and early adopters) and the mainstream majority (early and late majority, and laggards).

\section{Factors influencing rate of adoption of innovation}

Rogers also held the view that the features of an innovation influence its rate of adoption (Rogers 1995; pp.250-251). The rate of adoption will increase depending on the factors listed below (Donovan, 1999). This framework has been utilised by several institutions to design staff development activities discussed later in this paper. A set of simple questions like these below assist the staff developer to consider the 'innovation' from the eyes of the mainstream majority, and not always the early adopters:

- Advantage - Does the innovation indicate an advantage over current ways of doing things?

- Compatibility - Is the innovation compatible with existing needs and expectations?

- Complexity - Does the innovation make life simpler or at least not contribute more complexity?

- Trialability - Can the innovation be tried without a commitment to completely change the current practices?

- Observability - Is the innovation observable and visible to potential adopters?

\section{Institutional approaches to staff development}

For the adoption of new learning technologies in learning and teaching across an institution, staff development strategies need to focus on achieving a critical mass of staff that are competent online teachers and to enhance the institution's capability to sustain the integration of new technologies into learning and teaching practices. Some institutional approaches to this challenge are explored below.

\section{Characteristics of innovation}

Several universities have deliberately drawn on Rogers' characteristics of innovation as a framework for staff development (Donovan, 1999; Donovan \& Macklin, 1999; McLoughlin, 2000; Litchfield, 2000) and utilised diverse approaches to address the needs of the mainstream majority, 
including workshops, short courses, action learning projects, and website support. Taking a whole of institution approach to address this group of staff raises particular challenges for the staff developer: shifting focus from customised solutions that meet the needs of individual teachers to strategies that can move the mainstream majority to adoption of innovation. In seeking to develop the skills of the online teacher, strategies must include not only teaching the technical skills required to use the software and the learning management system that distributes the course to the student, but also teaching instructional design skills in order that the teacher can integrate the interaction that has traditionally been part of classroom teaching, into the online environment. A solution to this problem may be found in staging the development of teachers' skills to match the degree of web based support offered in online courses. This approach to staff development is discussed later in this paper.

\section{Competencies of online teachers}

A competent, confident online teacher is a new and different role for academic staff. The major roles of a competent online teacher have been outlined as (Goodyear, Salmon, Spector, Steeples \& Tickner, 2001):

- The role of content facilitator, concerned directly with facilitating the learners' growing understanding of course content;

- The role of technologist, concerned with making or helping make technological choices that improve the environment available to learners;

- The role of designer, concerned with designing worthwhile online learning tasks;

- The role of manager/administrator, concerned with issues of learner registration, security, record keeping, etc;

- The role of process facilitator, concerned with facilitating the range of online activities that are supportive of student learning;

- The role of adviser/counsellor, concerned with offering advice or counselling to learners on an individual or private basis to help them get the most out of their engagement with the course;

- The role of assessor, concerned with providing grades, feedback, and validation of learners' work; and

- The role of researcher, concerned with engagement in production of new knowledge of relevance to the content areas being taught.

Six main task areas for the process facilitator role have also been identified: welcoming, establishing ground rules, creating community, managing communication, modelling social behaviour, and establishing own identity (Goodyear et al., 2001). The facilitator role is the competency area that is closely aligned to Northrup's framework of interaction attributes 
discussed earlier in this paper (Northrup, 2001), and supports the maintenance by the teacher of an online presence.

The competencies as described above have been used as the basis for the design of a Graduate Certificate in Online Teaching and Learning at Edith Cowan University, aimed at development of teachers' abilities to teach effectively using information and communication technologies (Herrington and Oliver, 2001). In another context at the Royal Melbourne Institute of Technology (RMIT), a competency framework provides the support to build the skills and knowledge required of teaching staff to use a courseware delivery system effectively (Kenny, Quealy \& Young, 2002). In both examples the teachers-as-learners are actively engaged in activities and tasks that causes them to explore new ways of designing courses and resource materials for the online environment.

\section{Accredited courses}

Higher education institutions use formal, accredited courses for academic staff as a vehicle for diffusion of staff development in new learning technologies. One Australian example at Monash University (Edwards, Webb \& Murphy, 2000) addressed institutional embedding of a Graduate Certificate in a number of ways: making the first unit of the formal program a requirement for all new teachers entering the university, linking completion of the course to a probationary requirement, marketing the course to institutional leaders, and using the project component of the course as a vehicle for attracting staff with specific departmental aims they wished to achieve. In the UK an evaluation study of the implementation of an Advanced Diploma in Information and Communication Technology (APDICT) drew some valuable conclusions for this formalised approach to the provision of 'meaningful' staff development in new learning technologies: setting clear parameters around entry requirements, achieving the right balance between theoretical understanding of the technology and practical applications, and designing the course so that specific needs of teams of learners in specific contexts are addressed (Clegg, Konrad \& Tan, 2000). A study reported by Littlejohn (2002) into accredited continuing professional development (CPD) courses for staff at her institution in Scotland found significant improvement in online course design by those staff participating in one module as a result of incorporating into the design of the module a focus on incremental change in participants' move to online teaching, providing opportunities for dialogue and reflection amongst participants as they moved through the module, using project based learning as the framework, and providing appropriate technical skills to staff on a need to know basis. 


\section{Staff development online}

Delivering staff development online is another strategy to develop the skills and knowledge of online teachers. Several reasons provide the rationale for this approach: limitations of face to face, centralised, workshops (Salter \& Hansen, 2001; Hewson and Hughes, 1998); teachers taking control of their own professional development (Stuckey, Lockyer \& Hedberg, 2001); empowering the academic staff member to make connections with their own experience and knowledge (Bennett, Priest \&

Macpherson, 1999), putting the staff member in the position of the online student (Devonshire \& Philip, 2001); increasing accessibility and enhanced opportunities for communication amongst staff, and decreasing the amount of face to face workshops (Drysdale \& Creanor, 1998); learning by example (Wills, 1998); complementing traditional methods (MacKenzie \& Staley, 2000), providing opportunities for staff separated geographically to work collaboratively across the institution (Kandlebinder, 2001). In some cases moving staff development online has meant the provision of specific courses online, some with some face to face components, or the design and development of websites that act as content resources. A number of frameworks underpin the learning design of these online courses: the work of Biggs (MacKenzie and Staley, 2000); Lave \& Wenger (Stuckey, Lockyer et al., 2001); and Brown, Collins \& Duguid (Taylor, 2003); and the Australian Vice-Chancellor's Guidelines for Effective University Teaching (Collom, Dallas et al., 2002), to name a few. Collectively these principles can be summarised as follows:

- Online staff development should encourage deep learning approaches through a sound motivational structure, well-structured knowledge base, learner activity and interaction with others;

- Online staff development should focus on workplace practices and enable the sharing and pooling of knowledge amongst academic staff;

- Online staff development should provide authentic contexts for staff development and opportunities for participants to critically reflect on their learning as they progress through course; and

- Online staff development should be based upon research into teaching and learning and good practices in institutions.

\section{Localised peer support}

Some institutions have adopted a localised, faculty based approach to provision of staff development, situating it in the context of the school or department, with staff appointed to work alongside of and provide peer support to others engaged in adopting new technologies in teaching and learning, building on good practices that already exist. RMIT in Victoria through their IT Alignment Program introduced a Learning Technology 
Mentor Program (LTM) from 1999 to mid 2001 to achieve widespread adoption of online learning. Most of these staff were innovators/early adopters (McNaught, 2003). At Charles Sturt University in regional New South Wales, Faculty Online Support Coordinators (FOSCs) were appointed initially to facilitate the development of online courses; however, over time their role shifted to supporting development of academics' awareness of technology and how it could be used in teaching (Kirkpatrick, 2001). At the University of Western Australia, a network of local staff within each faculty were appointed (CATLysts) supported by the centralised staff development unit to respond to the need for consistent and effective adoption of online teaching (Ingram \& Thompson, 2001).

A very recent example of formalised peer support is the introduction at Deakin University in Victoria of the Deakin Online Teaching Fellows. This program, currently in its first year, has provided funding to faculties to release one or two academic staff members from part of their teaching duties to undertake intensive technical and pedagogical sharing and support as they develop their own teaching units into a new Learner Management System. After the Online Fellows have successfully piloted their projects, they will become faculty experts, with knowledge of the wider university support structure, who can help their colleagues learn and problem solve as they migrate to or develop their courses within the new technological system. Despite variations between institutions regarding the appointment of these staff and their roles, common approaches include the provision of opportunities to share expertise, the mentoring of staff, the development of networks of staff (internal and external to the faculty) that foster collaboration and learning from others, and that focus on the use of technologies in relation to specific disciplines and project teams.

\section{Levels of need and stages in staff development}

Finally, some institutions have approached development of staff from the perspective of designing support that is aligned to the levels of need and/or readiness levels of the academic staff. (Tinkler, Lepani et al., 1996; Crock and Andrews, 1997; Haigh, 1998; Wills, 1998; Bennett, Priest et al., 1999; Ellis and Phelps, 2000; Hadgraft, Prpic et al., 2001; Collom, Dallas et al., 2002). Table 1 below summarises these stages in learning and staff development content appropriate for the particular stage. One way of viewing this approach is to see it as the staging of a change process through which individual staff members progress, supported by delivery of the right mix of skills and knowledge appropriate to staff needs at the time. This resonates with a widely held view in the literature that staff development for change and diffusion of innovation needs to be delivered 'just in time', and be grounded in specific, local contexts. 
Table 1: Matching levels of needs of academic staff to content of staff development

\begin{tabular}{|c|c|c|}
\hline Levels & $\begin{array}{l}\text { Description of } \\
\text { staff at this level }\end{array}$ & $\begin{array}{l}\text { Staff Development } \\
\text { content and approach }\end{array}$ \\
\hline Level 1 & $\begin{array}{l}\text { Beginners, novice, lack of } \\
\text { familiarity with online } \\
\text { teaching, lack of experience } \\
\text { with technology in teaching. } \\
\text { Aware of innovation using } \\
\text { technology in teaching, } \\
\text { Varying levels of interest in } \\
\text { technology amongst staff at } \\
\text { this level, some are reluctant. } \\
\text { - Primary need is the } \\
\text { identification of } \\
\text { opportunities to use } \\
\text { technology effectively }\end{array}$ & $\begin{array}{l}\text { 'Show and Tell' activities, } \\
\text { operational training, short seminars } \\
\text { on current activities within the } \\
\text { institution, guest speakers, and } \\
\text { exemplars. }\end{array}$ \\
\hline Level 2 & $\begin{array}{l}\text { - Advanced beginner, limited } \\
\text { exposure, required to use } \\
\text { technology } \\
\text { - Some experience in teaching } \\
\text { in flexible learning } \\
\text { environments } \\
\text { - 'Learning the process' }\end{array}$ & $\begin{array}{l}\text { Stage } 1 \text { activities plus instructional } \\
\text { design skills, skills in online } \\
\text { pedagogy, learning management } \\
\text { system skills, skills in use of email, } \\
\text { discussion boards, role play and } \\
\text { debates to increase interactivity } \\
\text { online. More reflection encouraged } \\
\text { at this stage to consolidate staff } \\
\text { theoretical knowledge; project- } \\
\text { based learning. }\end{array}$ \\
\hline Level 3 & $\begin{array}{l}\text { Want to try things out; want } \\
\text { to use online learning } \\
\text { environments, still may have } \\
\text { limited skills and exposure to } \\
\text { technology in teaching. } \\
\text { - Implementing the innovation } \\
\text { in their work } \\
\text { - Exploring and experimenting } \\
\text { - Applying the process }\end{array}$ & $\begin{array}{l}\text { Stage } 1 \text { and } 2 \text { skills plus focus on } \\
\text { more complex technical knowledge, } \\
\text { more complex forms of interactivity } \\
\text { online (eg. collaborative group } \\
\text { learning), preparing staff to handle } \\
\text { problems of more intensive online } \\
\text { discussions (eg. flaming, lack of } \\
\text { responses); case studies are useful } \\
\text { approach with this stage of } \\
\text { development }\end{array}$ \\
\hline Level 4 & $\begin{array}{l}\text { - Competent } \\
\text { - Advanced } \\
\text { - } \text { Proficient } \\
\text { - Imprt } \\
\text { - Consoling the innovation of skills and } \\
\\
\text { learning }\end{array}$ & $\begin{array}{l}\text { Staff at this stage become role } \\
\text { models for others, act as resource } \\
\text { for other staff, providing advice, } \\
\text { engaged in research and } \\
\text { development focussed activities, can } \\
\text { be used as formal and informal } \\
\text { participants in a staff development } \\
\text { program }\end{array}$ \\
\hline
\end{tabular}




\section{Implications for staff development}

The theories, models and practices discussed so far provide a basis for selecting and developing the most appropriate strategies for each specific situation. Models are continually evolving as research and practice are analysed and reported but some important implications for consideration are presented below.

1. In diffusing the take up of technologies in teaching and learning, the work of the early adopters, their knowledge, skills and experience can be built on, but the focus needs to be on the mainstream majority and the support they require. A staged approach can be used to the appropriation of technology, with design of a staff development program that uses incremental steps to match readiness levels of the mainstream staff and exposes them to a less risky journey to moving online. Clear definitions of the entry level technical skills and the content appropriate for each step need to be provided.

2. The attributes of adoption of an innovation can be used. If the reasons why the mainstream staff are more inclined to accept an innovation are analysed and emphasised, the potential advantages for staff, students and the institution can be provided as a credible rationale.

3. A focus on local and discipline based ideas and practices, peer support and mentoring approaches can provide a relevant approach. If projects and project teams within schools or departments are the context for staff development, they provide authentic purpose and deploy support staff in context for a more effective result. As staff practise the newly learned skills as they are needed, and seek expert or experienced pedagogical advice as it is required, staff development will be relevant and implemented.

4. An emphasis on innovation, rather than the technology should be adopted. If an environment is created that supports opportunities for staff to trial new teaching and learning methods, and that encourages them to support each other and share knowledge and skills, it has a greater likelihood of success.

5. The competency frameworks that are appearing in the literature can be used as guides to the content and focus of staff development for online teaching. Specific roles, for example Process Facilitator, could be the focus of workshops, with face to face and online components. The online teacher needs to understand not only the technical platform being used to support online teaching, but also requires the design skills necessary to avoid the 'dumping' of content used in classroom based contexts into the online environment. 
6. Authentic contexts to situate learning activities should be used within the staff development program. Opportunities should be provided for staff to share experiences, ideas, and reflections with others as they engage as learners. Staff development activities can be designed that combine online and face to face learning opportunities so that staff experience learning online from the learner's perspective.

7. Accredited courses that focus on using information and communication technologies in teaching can be embedded into the organisation by making either all or parts of the course a requirement for beginning teachers, for probation, or for performance review.

\section{Conclusion}

In considering the themes of the conference, interact, integrate and impact, this paper has discussed the reasons why, as well as the way, technologies have provided increased opportunities for teachers and learners to interact with each other in both on and off campus settings and has described the impact this has had on the expectations for academic staff to integrate the use of technologies into their teaching. The theorising and research about the diffusion of innovation have suggested that staff do not embrace change at the same pace, or in the same way, with some more reluctant than others to adopt new technologies into their practice. Understanding of the factors that influence adoption of innovation is valuable for determining the design and content for staff development programs aimed at integrating the online environment into all institutional teaching. This paper has described many approaches that can be used successfully to shape staff development activities to help staff integrate technologies into their teaching through designing and establishing teacher presence online, and thereby facilitating interaction with their students, as institutions develop and constantly change their e-learning environments.

\section{References}

Anderson, T., Rourke, L., Garrison, D.R. \& Archer, W. (2001). Assessing teaching presence in a computer conferencing context. Journal of Asynchronous Learning Networks, 5(2) [7 Sep 2003]

http: / / www.aln.org/publications/jaln/v5n2/v5n2_anderson.asp

Anderson, T., Varnhagen, S., \& Campbell, K. (1998). Faculty adoption of teaching and learning technologies: Contrasting earlier adopters and mainstream faculty. The Canadian Journal of Higher Education, 28(2, 3), 71-98.

Australian Vice-Chancellors' Committee (1993). Guidelines for Effective University Teaching. [27 Jul 2003]

http:/ / www.avcc.edu.au/news/public_statements / publications/gleffut.htm 
Bennett, S., Priest, A.-M., \& Macpherson, C. (1999). Learning about online learning An approach to staff development for university teachers. Australian Journal of Educational Technology, 15(3), 207-221.

http: / / www.ascilite.org.au/ajet/ajet15/bennett.html

Berge, Z. (1999). Interaction in post-secondary web-based learning. Educational Technology, 39(1), 5-11.

Biggs, J. (1999). Teaching for quality learning at university. Buckingham, UK: Society for Research into Higher Education and Open University Press.

Bonk, C. \& Cunningham, D. (1998) Searching for learner-centred, constructivist, and sociocultural components of collaborative educational learning tools. In C. J. Bonk, \& K. S. King (Eds.), Electronic collaborators: Learner-centred technologies for literacy, apprenticeship, and discourse (pp. 25-50). Mahwah, NJ: Erlbaum.

Brown, J. S., Collins, A., \& Duguid, P. (1989). Situated cognition and the culture of learning. Educational Researcher, (January-February), 32-42.

Bullen, M. (1998). Participation and critical thinking in online university distance education. Journal of Distance Education, 13(2), 1-32.

Clegg, S., Konrad, J. \& Tan, J. (2000). Preparing academic staff to use ICTs in support of student learning. The International Journal for Academic Development, $5(2), 38-148$.

Collom, G., Dallas, A., Jong, R. \& Obexer, R. (2002). Six months in a leaky boat: Framing the knowledge and skills needed to teach well online. Proceedings ASCILITE 2002, December 8-11. Auckland, New Zealand [24 Jan 2004] http:/ / www.ascilite.org.au/conferences/auckland02/proceedings/papers/181.pdf

Deakin University (2003). Code of good online practice. [26 Jul 2003] http: / / theguide.deakin.edu.au $/$ TheGuide.nsf $/$ Web+Visitors?OpenFrameSet\&Frame=W
ebContent\&Src=WVisAPPAlaz?OpenView\&Choice=2\&Access=Visitor

Devonshire, L. \& Philip, R. (2001). Managing innovation and change in flexible times: Reflecting on the role of the educational developer. Paper presented at the Open and Distance Learning Association of Australia (ODLAA) 15th Biennial Forum, 21-24 September. Sydney, New South Wales.

Donovan, M. (1999). Rethinking faculty support. The Technology Source, September/October. [27 Jul 2003]

http: / / ts.mivu.org/ default.asp?show=article\&id $=612$

Donovan, M. \& Macklin, S. (1999). The Catalyst project: Supporting faculty uses of the web...with the web. CAUSE/EFFECT, 22(3). [27 Jul 2003] http:/ / www.educause.edu/ir/library/html/cem9934.html

Drysdale, J., \& Creanor, L. (1998). Leading new teachers to learning technology. In Learning Technology Dissemination Initiative (LTDI): Evaluation Studies, 13-18. [28 Jul 2003] http:/ / www.icbl.hw.ac.uk/ltdi/evalstudies/esleading.pdf 
Edwards, H., Webb, G., \& Murphy, D. (2000). Modelling practice - Academic development for flexible learning. The International Journal for Academic Development, 5(2), 149-155.

Ellis, A. \& Phelps, R. (2000). Staff development for online delivery: A collaborative, team-based action learning model. Australian Journal of Educational Technology, 16(1), 26-44. http:/ / www.ascilite.org.au/ajet/ajet16/ellis.html

Flottenmesch, K. (2000). Building effective interaction in distance education: A review of the literature. Educational Technology, 40(3), 46-51.

Garrison, D. R. \& Anderson, T. (1998). Learning in a networked world. In C. Campbell-Gibson (Ed), Distance learners in higher education: Institutional responses for quality outcomes (pp. 97-112). Madison: Atwood Publishing.

Garrison, D. R., Anderson, T. \& Archer, W. (2000). Critical thinking in a text-based environment: Computer conferencing in higher education. Internet and Higher Education, 11(2), 1-14.

Geoghegan, W. (1995). Stuck at the barricades: Can information technology really enter the mainstream of teaching and learning? Change, 27(2), 22-30.

Goodyear, P., Salmon, G., Spector, J. M., Steeples, C. \& Tickner, S. (2001) Competencies for online teaching: A special report. Educational Technology Research and Development, 49(1), 65-72.

Herrington, J. \& Oliver, R. (2001). Online learning: Professional development for the changing role of the lecturer. Paper presented at the Moving Online Conference II (September 2-4, 2001). School of Social and Workplace Development, Southern Cross University, New South Wales. [26 Jul 2003] http: / / www.scu.edu.au/schools/ sawd/moconf/ papers2001/ herrington.pdf

Hewson, L., \& Hughes, C. (1998). On-line and on-demand: Staff development in the new university. Paper presented at the Educause in Australasia Conference, 18-21 April. Sydney, New South Wales.

Ingram, D., \& Thompson, E. (2001). Catalysts for change: A university network for advancing teaching and learning. Proceedings of the 24th International Higher Education Research and Development Society of Australasia (HERDSA) Conference, 8-11 July. University of Newcastle, New South Wales.

Jacobsen, M. (2000). Excellent teaching and early adopters of instructional technology. Paper presented at the ED-MEDIA 2000: World Conference on Educational Multimedia/Hypermedia \& Educational Telecommunication, 26 June-1 July. Montreal, Quebec, Canada.

Kandlbinder, P. (2001). Peeking under the covers: Understanding the foundations of online academic staff development. Flexible Learning for a Flexible Society. Proceedings ASET-HERDSA 2000, 2-5 July. University of Southern Queensland, Toowoomba, Queensland [verified 26 Jan 2004] http:/ / www.aset.org.au / confs / aset-herdsa2000/ procs / kandlbinder2.htm 
Kenny, J., Quealy, J., \& Young, J. (2002). RMIT ICT DLS competency framework - A basis for effective staff development. UltiBASE (November 2002). [verified 26 Jan 2004] http:/ / ultibase.rmit.edu.au/Articles/nov02/kenny1.htm

Kirkpatrick, D. (2001). Staff development for flexible learning. The International Journal for Academic Development, 6(2), 168-176.

Litchfield, A. (2000). Diffused staff development to support integrating information technology into the curriculum. Proceedings ASCILITE 2000, 9-14 December. Southern Cross University, Coffs Harbour, NSW.

http:/ / www.ascilite.org.au/conferences/coffs00/papers/andrew_litchfield.pdf

Littlejohn, A. (2002). New lessons from past experiences: Recommendations for improving continuing professional development in the use of ICT. Journal of Computer Assisted Learning, 18(2), 166-174. [verified 9 Feb 2004]

http:/ / www.strath.ac.uk/Departments/CAP/allison/papers/jcal/newlessons.html

MacKenzie, N., \& Staley, A. (2000). Online professional development for academic staff: Putting the curriculum first. Innovations in Education and Teaching International, 38(1), 42-53.

McLoughlin, C. (2000). Creating partnerships for generative learning and systemic change: Redefining academic roles and relationships in support of learning. The International Journal for Academic Development, 5(2), 116-128.

McNaught, C. (2003). The effectiveness of an institution-wide mentoring program for improving online teaching and learning. Journal of Computing in Higher Education, 15(1), 27-45.

Moore, G. (1991). Crossing the chasm. New York: Harper Business.

Moore, M. G. (1989). Three types of interaction, American Journal of Distance Education, 3(2), 1-6.

Murphy, K., Smith, P. \& Stacey, E. (2002). Teaching presence in computer conferencing: Lessons from the United States and Australia. Proceedings of International Conference on Computers in Education (ICCE 2002), pp. 694-698, IEEE Computer Society Press, USA.

Rogers, E. M. (2003). Diffusion of innovations (5th ed.). New York: The Free Press.

Salter, G. \& Hansen, S. (2001). Facilitating web-based staff development in higher education. In L. Richardson \& J. Kidstone (Eds.), ASET-HERDSA 2000 Flexible Learning for a Flexible Society, 2-5 July 2000 (pp. 612-617). University of Southern Queensland, Toowoomba, Queensland. [verified 26 Jan 2004] http: / / www.aset.org.au/ confs/ aset-herdsa2000/ procs/hansen.html

Sims, R. (2003). Promises of interactivity: Aligning learner perceptions and expectations with strategies for flexible and online learning. Distance Education, 24(1), 85-103. 
Stacey, E. (1999). Collaborative learning in an online environment. Journal of Distance Education, 14(2), 14-33.

Stacey, E. (2002) Learning links online: Establishing constructivist and collaborative learning environments. In S. McNamara. \& E. Stacey (Eds) Untangling the web: Establishing learning links. Proceedings ASET 2002, July. http: / / www.aset.org.au/ confs / 2002/ stacey.html

Stuckey, B., Lockyer, L., \& Hedberg, J. (2001). The case for community: On-line and ongoing professional support for communities of practice. Paper presented at the Open and Distance Learning Association of Australia (ODLAA) 15th Biennial Forum, 24-27 September. Sydney, New South Wales.

Taylor, J. (2003). Managing staff development for online education: A situated learning model. Journal of Higher Education Policy and Management, 25(1), 75-87.

Taylor, P. G. (1998). Institutional change in uncertain times: Lone ranging is not enough. Studies in Higher Education, 23(3), 269-280.

Wenger, E. (1998). Communities of practice: Learning, meaning and identity. New York: Cambridge University Press.

Wills, S. (1998). Being flexible about flexible delivery. Paper presented at the Educause in Australasia Conference, 18-21 April. Sydney, NSW.

This article received an Outstanding Paper Award at ASCILITE 2003,
gaining the additional recognition of publication in AJET (with minor gaining the additional recognition of publication in AJET
corrections). The reference for the Conference version is:

Wilson, G. and Stacey, E. (2003). Online interaction impacts on learning: Teaching the teachers to teach online. In G. Crisp, D. Thiele, I. Scholten, S. Barker and J. Baron (Eds), Interact, Integrate, Impact. Proceedings 20th Annual Conference of the Australasian Society for Computers in Learning in Tertiary Education, pp541-551. Adelaide, 7-10 December: ASCILITE. http: / / www.adelaide.edu.au/ascilite2003/docs/pdf/541.pdf

Gail Wilson, g.wilson@uws.edu.au

Educational Development Centre, University of Western Sydney

Elizabeth Stacey, estacey@deakin.edu.au

Faculty of Education, Deakin University 